\title{
A Disciplined Freedom: The Paradox of Labour Rights in Post-Reformasi Indonesia
}

\author{
Rizma Afian Azhiim and Gema Ramadhan Bastari ${ }^{1}$
}

Received: 28 September 2018 | Accepted: 30 April 2019 | Published: 10 May 2019

\begin{abstract}
This paper will discuss the paradox of labour rights in Indonesia after the beginning of Reformasi in 1998. Despite workers having been provided with better regulations that uphold all of their essential rights, labour protests remain prevalent with the same demands every year. To explain this paradox, this paper will employ Foucault's concept of biopower to argue, that instead of bringing prosperity to workers, these new regulations have actually disciplined them. New regulations and freedoms have dictated and limited the kinds of actions that workers can undertake, constructing their logic and becoming internalised to the point that some do not realise that they are ironically being constrained by the very laws that were supposed to free them. As such, workers have unknowingly become trapped in a cycle of protest-new government policy-protest ad infinitum. This paper concludes that "Reformasi" has not done much to improve workers' prosperity. The Manpower Law and freedom of association have failed to guarantee the fulfilment of labour rights, instead giving a false sense of freedom. To escape this trap, the labour movement must find a way to fight outside of the logic provided by the Manpower Law by beginning to imagine a system where labour exploitation can no longer exist.
\end{abstract}

Keywords: Labour rights, freedom, biopower

\section{Introduction}

Ever since the beginning of political reform, known as Reformasi, in 1998, Indonesia has undergone significant progress in its regulation of labour rights. Most notably, Law No. 13 of 2003 on Manpower set standards for the relations between employees and employers and emphasised the importance of wage standards, maternity leave, and (most importantly) freedom of association (Law No. 13 of 2003 on Manpower). This law led to the creation of many labour unions in Indonesia, which in turn provided more protection for the welfare of Indonesian workers. However, despite

The authors are affiliated with Universitas Indonesia and Aliansi Pemuda Pekerja Indonesia (APPI). 
the protection of labour rights through regulations and unions, labour protests against long and arduous working hour and relatively low wages have remained common in Indonesia (TURC, 2014). This problem is also apparent if we look at the falling purchasing power of Indonesia's middle and lower classes (Sasongko, 2016). This phenomenon reinforces the idea that workers have yet to prosper, despite the rights and powers given unto them.

Every year, the same thing is yelled by workers who are demonstrating in the streets: "Increase our wages!" Despite the numerous problems plaguing industrial relations, including the exploitation of the workforce by paying wages below the 'real' surplus value of the commodities produced, the informalisation of labour (especially labour at the fringe of the value chain, e.g. domestic workers, outsourced workers, etc.), and-most importantly-the power gap between the working and capital-owner class, Indonesian labour movements return to the issue of wages year after year. Although wage increases do contribute to better living conditions to some extent, they cannot eliminate the more structural problems mentioned previously. Furthermore, wage increases are traditionally implemented in-line with increased commodity prices, meaning that the burden borne by workers remains practically the same. All of these problems point to a single question: "under what circumstances do labour movements continue to push ineffective demands despite all of the freedom they have gained in the era of Reformasi?"

This paper argues that every apparatus employed by the Indonesian government during the Reformasi era to provide workers with freedom have actually disciplined them. This paradox will be explained using Foucault's concept of biopolitics, which explains how liberal governments use their power to subtly discipline individuals' desires. Furthermore, this paper will use discourse analysis to compare the implementation of sovereign power employed before and biopower after the beginning of Reformasi. In the end, this paper will highlight how Reformasi has changed the dynamics of labour movement, perhaps for the worse. 


\section{Reflection on Indonesian Labour Studies}

The field of labour studies in Indonesia is constantly evolving, and always seems to coincide with the zeitgeist of its time of publication. In times of political struggle, workers are usually characterised as the epicentre of resistance from below. This harkens back to early post-colonial era, when Sjahrir (1956, pp. 24 $25)$ proclaimed that the energy of resistance is not centred in the young and intellectual upstarts (who claimed to be the main drivers of the proclamation of independence) but in the common people, "especially the organised labourers who have a sharp consciousness and understanding of labour struggles in the world". Such studies usually employ class-struggle analysis to see the workforce as being in an antagonistic relationship with the dominant political-economic structure: capitalism. In this case, Sjahrir argued for 'people-centred governance' to ensure that the state can always promote the interests of its people without necessarily adhering to the hegemony of the global capitalist regime. However, as noted by Hadiz (2004), Sjahrir merely used labour as a pretext for his criticism against the increasingly fascist government of President Soekarno; meanwhile, his proposal to address the contemporary situation sorely lacked a coherent social basis. Nonetheless, Sjahrir's argument remains useful as a showcase for this type of Indonesian labour study.

Studies framing labour as the main driver of resistance from below were also quite popular in the early years of Reformasi. After the fall of Soeharto, many scholars highlighted the role of labour movements in this feat. Such studies argued that labourers had been among the first actors to effectively organise themselves against the New Order regime due to their direct experiences with the repressive policies employed by the regime (Soegiri \& Cahyono, 2003); as such, they also reaped the most benefits out of the regime change (Hadiz, 2002). Workers were also argued to be better acquainted with historical materialism, enabling them to understand the structure around them can affect their capacities as individuals (Ismail \& 
Basir, 2012). Some scholars argued that workers had remained major actors in the new political constellation after Reformasi. However, most scholars would argue that labour's role in this context was rather limited. Hadiz (1998) argued that this is because the Reformasi movement was dominated by 'middle-class intellectuals and politicians with few links with the labour movement' - a situation similar to that in the early post-colonial era. The dominance of the middle-class within the Reformasi movement, in turn created an oligarchy that enabled the creation of an elite-oriented political infrastructure that benefited them the most (Hadiz, 2001). Max Lane (2018) argued, in this situation, grassroots-based organisations such as labour movements could exist, but lacked the power to leverage themselves into main actors in the new regime. In the new political constellation, workers merely served as the political vehicle of a few elites who represented the popular ideology of the time.

Contrarily, during times of political stability, labour studies in Indonesia tend to be dominated by research into how workers can coexist within the existing political economic structure. Such studies usually invoke human rights and justice perspectives. In this case, workers are seen as victims of unfair systems or business practices, e.g. low wages (Izzaty \& Sari, 2013), outsourcing (Nafila, Kristine, \& Wijaya, 2017), hiring of temporary workers (Maulinda, Dahlan, $\&$ Rasyid, 2016), lack of labour unions (Handayani, 2016), or even outright exploitation in the form of modern slavery (Hidayati, 2014). Given these many injustices, such studies tend to argue for better protection and fulfilment of labour rights by the State and employers, which they argue will benefit not only workers but also employers and the State itself. By championing this narrative, such studies practically turn labour rights problems into matters of morality and ethics. Workers are positioned as weak parties who must be pitied due to their upbringing, and the State and employers are the only parties able to alleviate their misery. In doing so, the very basic principle of the tripartite system, which emphasises on the equal position of labour, State, and employer, is undermined. 
Another problem found in many labour studies in Indonesia is they often fail to position labour rights movements as part of a class struggle to find a better economic system without industrial relations. Instead, they tend to position labour rights problems as arising from inadequate systems or regulations. As such, they tend to recommend, at best, legal advocacy or political reform. Furthermore, such studies often stress the importance of the libertarian concept of "win-win solution" or harmonisation between workers and employers (Utomo, 2005; Randi, 2017). This notion can even be found in the handbook socialising Law No. 21 of 2000 concerning Labour Unions, published by ILO:

"Workers are essential partners of employers in the process of production for the purpose of increasing the well-being of workers and their families. Therefore, in exercising the freedom to associate, labour unions, employers, and Governmental agencies are obliged to create harmonious and dynamic industrial relations in order to advance and sustain the company, as well as ensure the fulfilment of national interests (Simanjuntak, 2002)."

In the previous statement, so-called harmonious industrial relations are emphasised in guaranteeing the company's sustainability, because the company is seen as an entity that desires the sustainable well-being of labours, which also coincides with the interests and ideals of the Government of Indonesia. Such labour studies, thus, are liable to contribute to the preservation of industrial relations and unequal power relations between workers and employers; as such, their ideal win-win solutions would most likely be undermined. More importantly, such studies also tend to focus on how workers can contribute to national economic growth instead of their own well-beings, as a prosperous country is assumed to mean a prosperous people-which is rarely the case. In other words, such studies fail to reflect on the origins of labour movements, which are created to oppose the biggest obstacle to labour prosperity, i.e. the capitalist system that allows unequal power relations to exist in the first place.

The main problem of worker-employer relations is not simply 
what libertarians refer to as the promotion of happiness and wellbeing in harmony for the purpose of moral, political, and individual decision-making (Mill, 2004). Social relations of production exist between workers and employers within "the conditions under which they exchange their activities and share in the total act of production" (Marx, 2009, p. 16). These conditions vary "according to the character of the means of production" (Marx, 2009, p. 16) and "the various economic epochs of the social structure" (Marx, 1978, p. 120; Burnham, 2001, p. 105). In such conditions, the social relations of production become more than a simple problem of morality. As such, rather than being seen as moral-based endeavours, labour movements should be seen part of the social process of capitalism within capital, class, and political contestation.

Paradoxically, capitalism not only works in the form of "fair trade and commercial freedom" between subjects of production (Foucault, 2008b, p. 64), but also runs in an 'antagonistic' form which contains social relations based on "exploitation between the capitalist and the labour" (Marx, 1978, p. 110). Given these paradoxical forms and the complexities of social relationships, we seek an approach to labour studies in Indonesia that develops and applies the social ethics of economic relations and social policy to achieve happiness, well-being, and worker-employer harmonisation. Referring to Foucault's perspective, which views the "problematic relationship between the production of freedom and that which in the production of freedom risks limiting and destroying" (Foucault, $2008 \mathrm{~b}$, p. 64), we try to examine the freedom of association for workers in the Reformasi era.

\section{The Power Relations between Freedom and Security in Biopolitics}

The concept of biopolitics stems from Foucault's analysis of the transformation of the modes and technologies of power. The first transformation was the reinterpretation of sovereign power into biopower during the 17th century. Sovereign power is characterised 
by vertical power relations involving the forceful subjugation of commodities, products, services, and even the lives of the ruled subjects. Meanwhile, biopower is a form of power that operates by managing, securing, and strengthening life; and letting the ruled subject live (Lemke, 2011).

In principle, Foucault identifies two forms of power over life (biopower), i.e. disciplining individual bodies and regulatory control over the population. Biopower, in the form of discipline, operates through security and control technology over individual bodies, which are perceived as machines. The goal of discipline is not repression, but rather increasing the economic productivity of the individual body while simultaneously weakening resistance to ensure political compliance (Lemke, 2011).

In the form of regulatory control, biopower is directed at the collective body of a population, i.e. a social body characterised by internal processes and phenomena such as the birth/mortality rates, health status, life expectancy, and welfare production. Regulatory control operates through technologies that secure the totality of the concrete processes of life within a population, which is done to protect or secure the population (as a biological entity) from internal risks and dangers (Lemke, 2011).

The second transformation, at least in regards of the birth of biopolitics, was the emergence of what Foucault refers to as liberal governments. Foucault does not see 'liberal' or 'liberalism' as an economic theory or political ideology, but as a specific art in the governance of human beings. In this regard, it has a different rationality from the concept of domination in the middle ages and the concept of logic in the early modern state era. The rationality of liberal governments refers to specific ideas on the nature of a society that became the foundation for and limitation of governance practice. Traits perceived as "the nature of society" offer a normative foundation for the practice of governance, and its power is operated not through direct regulation or prohibition, but rather through freedom, stimulation, and persuasion. The security mechanisms 
within liberal governments operate to protect and secure the naturalness of a free society that can self-regulate itself (Lemke, 2011, p. 47).

We believe that the Foucauldian concept of biopolitics constitutes many different ideas rooted in the writings of Michel Foucault and in scholarly debates. Lemke (2011, p. 47) comprehensively explores biopolitics, from its emergence to the many lectures and works of Foucault. Agamben (1995) adopts and revises the concept by deconstructing the relationship between power, knowledge, social life, and politics/law to operate the sovereign State and preserve its existence. Hardt and Negri (2000) use the concept of biopolitics to show the existence of an Empire, a transcendental power of global capitalism that reduces the sovereignty of the modern State.

From a review of the literature on biopolitics as a concept, we conclude that there are five core elements of biopolitics: i.e. power, knowledge, life, body (whether an individual's or a population's), and apparatus (the technology to discipline/control). Each element is interrelated with the other four. Foucault writes that power and knowledge are inseparable. Furthermore, the problem of powerknowledge relations is a fundamental one in historical studies of the genealogy of scientific knowledge, which offers the rationale for disciplining and controlling individual/population bodies through interrelated discourses that preserve and protect life while ensuring the survival of the body (Foucault, 1980a ; Foucault, 1980c, p. 109).

Interrelations between power, knowledge, life, body, and apparatus are also inferred by Agamben, who writes that the lives and deaths of human beings have been politicised through a power sustained by the knowledge of the importance of life and how life is supposed to be. According to Agamben (1995), the life and death narrative is a power for governing human life and is manifested in the laws, norms, and principles of sovereignty. Similar to Agamben, but with several differences in the interpretation of the manifestation of power and knowledge, Hardt and Negri (2000) explain that the 
relations between knowledge, life, body, and apparatus lie at the core of the biopolitical production that sustains the existence of sovereignty-whether the sovereignty of the State or the capitalism fragmented as an Empire, i.e. a transcendental power.

This paper will employ discourse analysis to examine the securement of the freedom of association within the context of labour movements. The biopolitical analysis of this paper will involve analysis of three sources of discourse: juridical discourse within labour and manpower regulations, narratives of labour movements, and narratives of labour-employer conflicts over wages.

\section{The Biopolitical Securement of Labour Movement through State Regulations}

Within sovereign nation States, regulation (as operated through bills of law) functions as a normative foundation for every citizen. At the same time, it also creates a security apparatus to discipline noncompliant bodies as well as exercise social control by establishing a hierarchical difference between those who are considered normal and abnormal, proper and improper, good citizens and bad, legal and illegal, well-behaved and criminal, etc. (Lemke, 2011, p. 47). The State's power, as exercised through legal regulation, continues to transform along with social conditions, as precipitated by scientific and technological innovations. Transformations within legal regulations create conditions of discontinuity within society, which is evidenced within historical episodes due to the continuous reproduction of social security through legal regulation.

Regulation, as a security apparatus and a normative foundation for society, is one element that sustains economic production and life within the territory of the nation State. In this case, legal regulation is also a technology and mechanism that provides the security and control necessary to ensure production and the stability of society's economic system. In fact, in the context of manpower, regulation has the goal of securing "harmonious industrial relations" between 
capital owners and workers for the sake of State sovereignty.

Through legal regulations, we can analyse the arrangements that make economic production possible. In Indonesia, the legal regulation that sustains production through the social relations between workers and employers has been implemented through the Manpower Law, which regulates industrial relations between capital owners/employers, workers/labour, and the government. As a social security and control technology, Indonesia's Manpower Law sustains economic production and life within the country, and transforms along with the social conditions in society to create specific historical periods. Through the concept of biopolitical power, adopted from the writings of Foucault, we can analyse how the Indonesian State's legal regulation works as a discourse in normalising wages, labour relations, and labour welfare to create conditions that enable the State, corporations, and society to sustain the social relations of production within the sovereign territory of the Republic of Indonesia.

\section{The Securement of Labour Movement during the New Order Era}

Using Foucault's biopolitics as a framework, it can be seen that the New Order regime sought to direct the collective body of the population (more specifically, labour movements) through the doctrine of Pancasila Labour Relations (Hubungan Perburuhan Pancasila/HPP), which was later renamed Pancasila Industrial Relations (Hubungan Industrial Pancasila). This doctrine emphasised that "labour, private businesses, and the state were components of one big harmonious family, with the state itself playing the role of benevolent father figure" (Hadiz, 2002, p. 132). The New Order regime justified labour's alienation as laying a foundation for social order and political stability (Purwaningsih, 2008, p. 143). However, such stability could only be sustained due to the use of Pancasila Industrial Relations to justify the government's use of punitive actions against inharmonious behaviour to ensure that the 
disappointment and alienation of the workforce would not develop into resistance.

Freedom of association is actually considered a human right due to advocacy led by the International Labour Organisation (ILO). However, before Reformasi, or more specifically before President Habibie ratified ILO Convention No. 87 on Freedom of Association, this right was not guaranteed by the Indonesian government (Tjandraningsih, 2007). When asked about its obligation to protect labour rights, the New Order regime would point to the Indonesian Trade Union (Serikat Pekerja Seluruh Indonesia/SPSI) as an avenue for protecting labour rights in Indonesia. However, SPSI's structure was dominated by individuals affiliated with the Golkar PartySoeharto's political vehicle. As such, SPSI was unable to be free of the government's power, and it ultimately became an apparatus of power through which the government implemented Pancasila Industrial Relations instead. Ultimately, efforts to fulfil labour's demands were always given less emphasis than the interests of employers, whom the New Order regime considered more important in sustaining Indonesia's economic growth (Levine, 2007).

Resistance against the authoritarian labour regime represented by SPSI can be seen in the establishment of new unions outside of SPSI, such as the Indonesian Welfare Labour Union (Serikat Buruh Sejahtera Indonesia/SBSI), which operated outside of the corridor expected by the government and directly challenged SPSI's legitimacy. This forced the New Order regime to deploy its resources, i.e. the military, by giving it the right to intervene in industrial relations disputes (Tjandraningsih \& Herawati, 2008). The New Order regime also used labour as an instrument of propaganda by establishing the doctrine of Pancasila Labour Relations as a unitary ideology to disconnect labour movements from socialist ideology by labelling them as communist - an ideology banned by the New Order. Instead of repressing the labour movement's desire to resist, these policies actually give birth to new figures of resistance that operated through non-union labour organisations funded by foreign 
grants, such as from Friedrich Ebert Stiftung (FES) Indonesia paid through the Indonesian Labour Foundation (Yayasan Tenaga Kerja Indonesia/YTKI) (Soegiri \& Cahyono, 2003). To top it all, the repressive policies implemented by the New Order regime found their 'Achilles heel' after the appearance of a martyr figure named Marsinah (Avonius, 2008, p. 105).

The atrocious murder and rape of Marsinah, a woman worker and labour activist from Sidoarjo, after she led a strike in 1993 enabled the fragmented labour resistance to unite through the establishment of the Solidarity Committee for Marsinah (Komite Solidaritas untuk Marsinah/KSUM) (Soegiri \& Cahyono, 2003, p. 38). According to Avonius (2008, p. 105), the tragedy of Marsinah's murder enabled labour movements to transform into civil society actors that were able "to change the political morality previously considered to be an absolute truth by the State." This tragedy also invited sympathy from neighbouring States, including Japan, Singapore, Australia, and the Philippines (Soegiri \& Cahyono, 2003, p. 39), who questioned the New Order regime's usage of the military to deal with labour issues. This, in turn, created pressure for the government to accept supervision by the United Nations (Avonius, 2008, p. 104). In the end, a more organised labour movement was capable of launching radical actions that were not predicted by the New Order regime (Tjandraningsih, 2007).

Looking back, the control of labour through terror and repressive policies has occurred in Indonesia since the colonial era, a fact highlighted by the torture of farm workers who refused to work, which ultimately paved the way for the creation of the Communist Party of Indonesia (Partai Komunis Indonesia/PKI) and its agenda of overthrowing the colonial government (Soegiri \& Cahyono, 2003). Indonesia's experiences under the colonial and New Order regimes show the fatal flaw of rule through vertical relations of fear. So-called times of "political stability" were not actually stable, as they were vulnerable to spontaneous acts of resistance that resulted from the accumulation of repressed workers' disappointment and 
alienation. Compared to labour movements in the Reformasi era, whose freedom of association is guaranteed by the State, labour movement actions under these regimes tended to be more disciplined and in-line with the legal expectations of the government. The next section will explain how freedom of association, as regulated by the Manpower Law, has allowed the discipline of the labour movement and ensured the security of the State.

\section{Transformation of the Securement of Labour Movements since Reformasi}

The beginning of Reformasi in 1998 traced its roots to economic, social, and political crises that resulted from a range of complex issues, including uncontrolled increases in foreign debt, bank credit, centralised executive power, collusion/corruption/ nepotism (korupsi/kolusi/nepotisme/KKN), high-cost economy, and business oligopoly. Reformasi was also driven by attempts to deregulate, privatise, and liberalise the market economy, increase human rights awareness, and demand democracy. The high point of Reformasi occurred on 21 May 1998, when President Soeharto resigned, signifying the end of the New Order regime. The new president, B.J. Habibie, immediately established the Cabinet of Development Reform (Kabinet Reformasi Pembangunan) to draft an agenda for the Reformasi era. A Special Council convened by Parliament in 1999 produced 12 reformist resolutions, including development reform; KKN eradication; a suggested election date; human rights; balancing central and regional finances; and promoting economic democracy (Ministry of Manpower, 2011, p. 21). During this period of political reform, labour movement arrangements also underwent transformations in three noteworthy aspects: freedom of association, improved working conditions, and resolution of labour-employer disputes. 


\section{Freedom of Association}

The political willingness to create more democratic conditions resulted in demand for the fulfilment of people's fundamental rights. In turn, these demands led to a political movement to promote fundamental reform in Indonesian governance and legislation. As such, post-1998 Indonesia experienced a wave of deregulation, privatisation, and liberalisation, as well as human rights enforcement. This also legitimised the provision of freedom of association, especially through the passage of a Law on Labour/ Trade Unions. At that time, many workers in Indonesia felt that they had regained the right to freely associate. This represented an important point in the guaranteeing of freedom of association, a process that began in 1998 with the passage of Presidential Decree No. 83 of 1998, which ratified ILO Convention No. 87 of 1948 on Freedom of Association and Protection of the Right to Organise. In subsequent years, Law No. 39 of 1999 on Human Rights and Law No. 21 of 2000 on Labour Unions provided workers with the freedom of association after 30 years of repression by the New Order regime.

Fundamentally speaking, the legitimacy of workers' freedom of association cannot be separated from the agenda and spirit of Reformasi, which created a raison d'etre to regulate workers' freedom of association in accordance with the State's constitution and goals. The provision of freedom of association was not only intended to guarantee “every person's right to associate, gather, and express opinions (Art. 28E of the 1945 Constitution of the Republic of Indonesia)", but also workers' freedom to associate with others in search of a just labour system that guarantees people's right "to work and receive payment and just treatment in labour relations (Art. 28D of the 1945 Constitution of the Republic of Indonesia)". Based on this raison d'être, the agendas, activities, and demands of labour movements in Indonesia were oriented towards improving regulations and thereby providing just, humane, and conducive 
working conditions, thereby reshaping the social relations of production between workers and employer.

\section{Improvement of Working Conditions}

The legitimacy of workers' freedom of association was directed towards improving working conditions, in-line with the State's interest in integrating the workforce into its national development programmes. After Reformasi, the State began to realise the importance of providing conducive working conditions for the sake of the national economy and production. In this regard, the State implemented an arrangement through which it could discipline and control industrial relations between workers and employers by guaranteeing the protection and fulfilment of workers' fundamental rights. Such a purpose was made explicit in the general explanation of Law No. 13 of 2003 on Manpower:

"The development of manpower must be arranged to fulfil the fundamental rights and provide the fundamental protections for workers as well as realise appropriate conditions for business development (Law No. 13 of 2003 on Manpower)."

After Reformasi began in 1998, previously existing rights and protections for workers were reproduced through the Manpower Law. Significantly, however, manpower regulations since 1998 have provided workers not only with fundamental rights, but also the legal ability to fight for their rights as well as mechanisms to ensure employer compliance. Since the passage of Law No. 13 of 2003 on Manpower, workers have been able to challenge employers' decisions or labour contracts in court. Furthermore, workers may file criminal reports against employers who pay less than minimum wage, employ children without parents' consent, employ children for more than three hours a day, employ children in heavy labour that disrupts their mental and physical development, exclude workers from pension program, employ foreign workers without authorisation, prohibit workers from conducting their religious 
ritual, fail to provide maternal leave, or obstruct/forbid workers from conducting strike (Art. 184 and 185 of Law No. 13 of 2003 on Manpower).

The amendments to the 1945 Constitution since 1998 have provided constitutional acknowledgement of the need to protect human rights in governmental legislation and policies. These constitutional amendments have also paved the way for a governance system that focuses more on freeing society. In fact, these amendments have also transformed how the State governs its citizens. Since 1998, the government has used a set of rationale that differs from the militaristic tendencies of Old and New Order regimes. Since Reformasi, the government's rationale has referred to an idea of the nature of society that limits how the government can act. For example, the post-1998 Indonesian State has positioned workers as a social group with an important role and position as an actor and objective of development. To be more precise, national development itself has been framed as human development, with workers being positioned as important actors and objectives that require special attention to increase their quality in tandem with human rights (Law No. 13 of 2003 on Manpower).

\section{Securement of Worker-Employer Disputes}

Every transformation of control arrangement, from dominating to "freeing", is always followed by the risk of chaos due to the existence of overlapping freedoms. In industrial relations, for example, such risk can manifest when workers-in the name of just and appropriate living conditions and fundamental human rightsdemand that employers provide astronomically high payments that are outside their capabilities. This can result in two scenarios: (1) employers may refuse workers' demands, driving workers to mobilise huge strikes; or (2) employers may refuse workers demands and close their companies (i.e. a lock-out). To avoid such scenarios, the government has sought to create third scenario as a solution 
that can preserve harmonious industrial relations: transforming the State into a lawful State, one that provides protection and legal certainty for all citizens under the State's jurisdiction. Such a solution has been implemented by the government of Indonesia, as explicitly expressed in the following passages from the amended 1945 Constitution of the Republic of Indonesia:

"The State of Indonesia is a lawful State (Art. 1 of 1945 Constitution) ... Every person deserves the same acknowledgement, guarantee, and legal certainty before the law (Art. 28D of 1945 Constitution) ... The right to live, the right to not be tortured, the freedom to think, the right to have religion, the right to not be enslaved, the right to be acknowledged as an individual before the law, and the right to not be charged retroactively under current laws, are human rights that cannot be abrogated under any condition ... In order to enforce and protect human rights under the principle of a democratic and lawful State, the implementation of human rights will be guaranteed, regulated, and provided in legislations (Art. 28I of 1945 Constitution)."

To implement power as a lawful State, the State requires a panoptic transformation to supervise, discipline, and control its citizens (Foucault, 1980b, p. 71). As such, the State must provide legal certainty, both material and institutional, to society. In the case of enforcing human rights for the sake of labour justice, as mandated by the amended constitution, the State has passed Law No. 21 of 2000 on Labour Union to guarantee workers the freedom of association. Through the right and freedom to associate, workers may establish an institution to represent themselves in negotiating with employers or even participate in drafting manpower regulation.

The freedom of association provided to workers by the State resulted in the inclusion of labour union representatives in the drafting of the Manpower Law. The State consulted with labour unions before enacting Manpower Law in 2003, and established a "Small Team" to monitor the process of drafting and legislating the law (Constitutional Court Decree No. PUU 012/PUU/I/2003, pp. 13, 59 and 102). Labour unions were not only included in the drafting of the law; they were also allowed to challenge it through 
the Constitutional Court. In 2003, for example, not long after the Manpower Law was passed, several labour unions challenged the law in the Constitutional Court on the basis that several of its provisions were incongruent with the constitution, especially in regards of human rights, which include termination (due to workers being "considered" to have conducted a crime but not receiving prosecution in court) and the limitation of the right to strike by including criminal penalties (Constitutional Court Decree No. PUU 012/PUU/I/2003). As a result, the Manpower Law has included many elements that can guarantee workers receive their labour rights. The production of manpower regulations did not stop with the passage of the Labour Union and Manpower Laws. The State recognised that freedom of association and the fulfilment of labour rights would be meaningless if it lacked an institution that could guarantee citizen compliance. As such, in 2004, the State passed the Law on the Resolution of Industrial Relations Dispute, which paved the way for the establishment of the Industrial Relations Court (Pengadilan Hubungan Industrial/PHI), enabling both workers and employers to make each other accountable through legal means.

\section{Ineffective Demands Arising from Ineffective Freedoms}

Despite providing workers with many freedoms and rights, all of the efforts mentioned above actually represent a panoptic supervision implemented only for the sake of realising 'harmonious' industrial relations. Freedom of association, the Manpower Law and the industrial relations court are, in essence, integral parts of the State's transformation into a panoptic lawful State. The transformation of the State into a lawful State has proven effective at moving conflicts that result from failed negotiations between workers and employers from factories and streets into courtrooms. Labour unions, thus, no longer need to mobilise their members to conduct strikes and employers no longer need to lock out their factories; they can simply bring the fight to the courtroom to resolve their disputes. 
Although currently labour strikes remain quite prevalent, twenty years of Reformasi have seen no huge strikes or lock-outs that could destabilise the economy or trigger economic crises. All that we have seen during this period are annual demonstrations to demand increased wages, which have eventually resulted in Government Regulation (PP) No. 78 of 2015.

PP No. 78 of 2015 can be seen as part of the current government's efforts to further discipline labour movements. Prior to the enactment of this regulation, labour unions were authorised to conduct monthly surveys on the need for a decent living (Kebutuhan Hidup Layak/KHL) to determine the appropriate minimum wage that must be received by workers in each region (Elucidation of Minister of Manpower Regulation No. 13 of 2012 concerning the Need for a Decent Living). As such, if the minimum wage was found to be lower than the results of the labour union's survey, workers could legally demand an increase in the minimum wage. However, upon the enactment of PP No. 78 of 2015, such surveys have been limited to once every five years (Art. 43 of PP No. 78 of 2015). As a replacement for monthly surveys, the regulation specifies a formula for determining the minimum wage based on the results of the fiveyear survey that involves the calculation of the annual inflation rate and GDP growth (Art. 44 of PP 78 of 2015). This rule effectively limits labour's opportunities to make lawful demands to increase wages. In other words, the annual demonstrations demanding increased wages have become ineffective due to the use of a rigid formula for determining the minimum wage.

According to its elucidation, the passage of PP No. 78 of 2015 represents a government response to the increasing complexity of worker-employer conflict over minimum wage:

"Workers see wages as their source of income for fulfilling the needs of workers and their family ... On the other hand, employers sees wage as one cost of production ... By taking into account the differing interests (of workers and employers), there is a need to converge workers and employers' understandings and interpretations of wage systems and regulations ... This Government regulation is expected to provide guidance in work 
relationships and dealing with the increasingly complex problem of wages (Elucidation of PP No. 78 of 2015)."

This regulation, thus, represents a move towards simplifying conflict over wages into a cold number-based economic formula which is claimed to objectively represent both the interests of workers and employers. In response to annual worker-employer conflict over wages, the government has tried to reach an objective understanding of wages. On one hand, workers employ a social perspective in defining their wages as their source of livelihood, while on the other hand employers use an economic perspective to define wages as a production cost. However, the government has attempted to establish its legitimacy "on the basis of a space of freedom for economic partners" (Foucault, 2008, p. 106). In doing so, the government has hijacked workers' social notion of wages by enforcing an economic perspective, i.e. the rigid economic formula, as the only solution to worker-employer conflict over wages.

According to Foucault (2008, p. 286), "economics is a science lateral to the art of governing". In this case, the birth of PP No. 78 of 2015 represents the rationality that the government must "govern with economics, alongside economists, and by listening to economists." However, the government's understanding of economics is perverted by its definition of economics in accordance with capitalism. The antagonistic nature of capitalism, which stems from social relations that are rooted in capitalist exploitation of labour, can be concealed. In the production process, capitalists create and acquire profit as employers through the extraction of surplus value from the work of their employees (Marx, 2009). Given this circumstance, wages will never be higher than the amount of surplus value that employers take from labour's work. Furthermore, employers have every interest to further increase the gap between workers' real work value and their wages in order to accumulate more profit. By limiting labour's opportunity to define wages, PP No. 78 of 2015 has essentially served the interests of capitalists. 
Regardless of the government's enforcement of an economic perspective in wage matters, workers' social notion of wage is not without its problems. Labour's understanding of wages as the main source of livelihood is supposedly a social rationality that opposes the economic rationality of wages as production costs. However, what most workers do not realise is that their livelihood is actually fundamental for capitalism's ability to work with labour as a means of production. As such, labour's social understanding of wages is essentially part of the autonomous process of producing surplus value, meaning that it is the constant reproduction of the social relationships that facilitate labour exploitation. This signifies the reality of labour becoming more biopolitical, which is implied by the "increasingly blurred boundaries between labour and life, and between production and reproduction" (Hardt \& Negri, 2009, p. 134). This is what has led to labour's inability to understand that their social relations are the essence of capital and that "life has now become . . . an object of power" (Foucault, 1994, p. 194; Hardt \& Negri, 2000, p. 24).

Therefore, in supporting the notion that their wages are the source of their livelihoods, workers have willingly complied with the very mechanism of capital accumulation. In addition, labour's demand for increased wages using the freedom of association given to them during the Reformasi era has allowed the government to create an indisputable control apparatus under the logic of economy/capitalism. This implies that freedom of association in this era is essentially a liberal 'freedom' that can only produce freedom under a certain set of "limitations, controls, forms of coercion, and obligation relying on threats, etc." (Foucault, 2008, p. 64). This ineffective 'formal freedom' is simply exploited by capitalists to generate more capital accumulation.

\section{Conclusion}

This paper concludes that there are three main circumstances 
that constitute the reality under which labour movements continue to push forward ineffective demands despite the freedoms they gained during the Reformasi era. The first is the transformation of the State of Indonesia from a sovereign-repressive State into a panoptic-lawful State, which enabled a biopolitical reality wherein the ruled subject (i.e. workers) willingly comply with the rules set by the State. The second circumstance is the implementation of freedom of association, which actually limits labour movements to the set of regulatory corridors set by the government. The third circumstance, finally, is the enactment of the Wage Law, which left labour's demand for increase wages irrelevant due to the use of a cold and rigid economic formula that is claimed to objectively represent both the concerns of labour and employers. Furthermore, this Law conceals the antagonistic nature of capitalism behind seemingly innocent economic science, which in turn misleads workers into thinking that demands for increased wages are actually meaningful.

Under these circumstances, union activists and intellectuals should begin to see the error in their libertarian perspective, which views worker-employer relations as being a matter of morals and ethics and refers to obstacles in the achievement of labour happiness and prosperity in harmonious industrial relations. The trajectory of the working class's struggle should be directed towards the creation of an autonomous economy that is from labour, for labour, and by labour. In such a trajectory, the numerous members of labour unions might be able to collectively accumulate the capital necessary to free themselves from dependence on the capitalistic social relations of production. Although the concept under which labour's independence from capitalism can be guaranteed is still far from clear, this is still a far more meaningful means of resistance than reproducing the same ineffective demands over and over again. As such, both union activists and intellectuals should begin to think about an alternative system wherein labour exploitation can no longer exist. 


\section{References}

Agamben, G. (1995). Homo sacer: Sovereign power and bare life (D. HellerRoazen, trans.). California: Stanford University Press.

Avonius, L. (2008). From Marsinah to Munir: Grounding human rights in Indonesia. In L. Avonius, \& D. Kingsbury, Human rights in Asia: $A$ reassessment of the Asian values debate (pp.99-109). New York: Palgrave Macmillan.

Burnham, P. (2001). Marx, international political economy and globalization. Capital \& Class, 25(3),103-112.

Foucault, M. (1980a). Body/power. In C. Gordon, Power/knowledge: Selected interviews and other writings 1972-1977 (pp. 53-62). New York: Pantheon Book.

Foucault, M. (1980b). Question on geography. In C. Gordon, Power/ knowledge: Selected interviews and other writings 1972-1977 (pp. 6377). New York: Pantheon Books.

Foucault, M. (1980c). Truth and power. In C. Gordon, Power/Knowledge: Selected interviews and other writings, 1972-1977 (pp. 109-133). New York: Pantheon Book.

Foucault, M. (1994). Les mailles du pouvoir. In M. Foucault, Dits et ecrits (pp. 182-201). Paris: Gallimard.

Foucault, M. (2008). The birth of biopolitics, lectures at the college de France 1978-1979. (A. I. Davidson, ed.) New York: Palgrave Macmillan.

Hadiz, V. (1998). Reformasi total? Labor after Suharto. Indonesia No. 66, 109-125.

Hadiz, V. (2001). Capitalism, oligarchic power and the state in Indonesia. Historical Materialism, 8(1), 119-152.

Hadiz, V. (2002). The Indonesian labour movement: Resurgent or constrained? Southeast Asian Affairs, 130-142.

Hadiz, V. (2004). The failure of state ideology in Indonesia: The rise and demise of Pancasila. In C. B. Huat, Communitarian politics in Asia (pp. 148-161). New York: Routledge.

Handayani, S. W. (2016). Jaminan pemerintah Negara Republik Indonesia terhadap penyelenggaraan serikat pekerja sebagai hak azasi manusia. Jurnal Kosmik Hukum. 16 (1), 1-12.

Hardt, M., \& Negri, A. (2000). Empire. USA: Harvard University Press.

Hardt, M., \& Negri, A. (2009). Commonwealth. Cambridge: Harvard University Press.

Hidayati, N. (2014). Perlindungan terhadap pembantu rumah tangga (PRT) 
menurut Permenaker No. 2 Tahun 2015. Jurnal Pengembangan Humaniora, 14(3), 213-217.

Ismail, I., \& Basir, M. Z. (2012). Karl Marx dan konsep perjuangan kelas sosial. International Journal of Islamic Thought, 1, 27-33.

Izzaty, \& Sari, R. (2013). Kebijakan penetapan upah minimum di Indonesia. Jurnal Ekonomi \& Kebijakan Publik, 4 (2), 131-145.

Lane, M. (2018). The impossibility of citizenship. International workshop on Power, Conflict \& Democracy 2018 (Handout). Yogyakarta: PCD Journal.

Lemke, T. (2011). Biopolitics: An advanced introduction. New York \& London: New York University Press.

Levine, M. J. (2007). Worker rights and labor standards in Asia's four new tigers: A comparative perspective. Berlin: Springer.

Marx, K. (1978). Capital (Vol. II). Middlesex: Penguin.

Marx, K. (2009). Wage-labor and capital. London: Dodo Press.

Maulinda, R., Dahlan, \& Rasyid, M. N. (2016). Perlindungan hukum bagi pekerja kontrak waktu tertentu dalam perjanjian kerja pada PT. Indotruck Utama. Kanun Jurnal Ilmu Hukum, 18 (3), 337-351.

Mill, J. S. (2004). Principles of political economy with some of their applications to social philosophy. Cambridge/Indianapolis: Hackett Publishing Company.

Ministry of Manpower. (2011). Perkembangan ketenagakerjaan di Indonesia. Jakarta: ILO Jakarta.

Nafila, Kristine, E., \& Wijaya, E. (2017). Perlindungan hak-hak buruh pada praktik sistem outsourcing: Sebuah "kesenjangan penerimaan". Jurnal Hukum Novelty, 8 (2), 252-256.

Purwaningsih, R. (2008). Konflik antar serikat buruh. Jurnal Bisnis dan Ekonomi, 15 (2), 143-148.

Randi. (2017). Buruh vs perusahaan: Studi kasus konflik buruh/pekerja driver Go-Jek dengan PT Go-Jek Indonesia. Social Work Journal, $7(2), 10-17$.

Sasongko, K. H. (2016, February 25). Menguak tabir ilusi kelas menengah. Indoprogress. Retrieved from https://indoprogress.com/2016/02/ menguak-tabir-ilusi-kelas-menengah/.

Simanjuntak, P. J. (2002). Undang-undang yang baru tentang serikat pekerja/ serikat buruh. Jakarta: ILO.

Sjahrir, S. (1956). Perdjuangan kita. Bandung: Jajasan Pendidikan Rakjat.

Soegiri, \& Cahyono, E. (2003). Gerakan serikat buruh: Jaman kolonial Hindia 
Belanda hingga orde baru. Hasta Mitra.

Tjandraningsih, I. (2007, August 21). Serikat buruh/serikat pekerja di Indonesia. Indoprogress. Retrieved from https://indoprogress. com/2007/08/serikat-buruhserikat-pekerja-di-indonesia/.

Tjandraningsih, I., \& Herawati, R. (2008, May 12). Dinamika jaringan perburuhan di Indonesia. Indoprogress. Retrieved from https:// indoprogress.com/2008/05/dinamika-jaringan-perburuhan-diindonesia/.

TURC. (2014). Lapsus: Refleksi perjuangan buruh di tahun 2014. Retrieved from TURC: http://www.turc.or.id/lapsus-refleksi-perjuanganburuh-di-tahun-2014/.

Utomo, I. S. (2005). Suatu tinjauan tentang tenaga kerja buruh di Indonesia. Jurnal The Winners, 6(1), 83-93. 